\title{
Development of Students' Assessment System to Conform Academic Standards at Faculty of Nursing Tanta University: A Case Study
}

\section{Rahma Soliman Bahgat}

Dean and Prof. of Pediatric Nursing Faculty of Nursing, Tanta University

\section{Azza Fouad Mohammed El-Adham}

Principle Investigator the Implementation Manager of the Project

Lecturer of Obstetrics and Gynecological Nursing, Faculty of Nursing, Tanta University

\section{Project Abstract:}

The development of students' assessment system at Faculty of Nursing Tanta University is a challenging area in nursing education. This case study aimed at exploring students' evaluation system at Faculty of Nursing Tanta University Tanta Egypt and presents and highlights the background, methods key findings and outcomes from the project of "Development of Students' Assessment System to Conform Academic Standards at Faculty of Nursing Tanta University" in order to provide a model for change and development of nursing education. The presented project was one of the competitive projects of the "Program of Continuous Improvement and Qualification for Accreditation" of higher education in Egypt. The evaluation project was sponsored by the Egyptian Ministry of higher education and Tanta University. The project objectives included four components: development of Code of Practice for students' evaluation, adoption of standardized competency-based assessments, adoption of an electronic system for students' evaluation, and formation of a Question Bank. The project duration was 18 months that was extended 6 more months as a result of the circumstances encountered by the country during the implementation of the project.

\section{Introduction:}

The process of the project included Assurance Center Tanta University Branch. declarations and commitments of the Endorsement Letter of Tanta University university, the faculty, the dean, the confirmed its commitment to and role in the principle investigator, the University Project-Management-Unit Director (UPMUD), and the Manager of Quality project "Development of Students' Assessment System to Conform Academic Standards at Faculty of Nursing Tanta 
University" with the Program of Continuous Improvement and Qualification for Accreditation through participation in the project by $40 \%$ (L.E 400,000 Egyptian pounds in cash) for attainment of the project objectives was conducted. The endorsement letter was printed on the official letterhead of the (partner) institution and stamped with the official stamp of the institution/PMU stamp. The Faculty of Nursing Tanta University developed two committees for the purpose of this project (the management and the implementation committees / teams) and an organizational structure endorsement letter of both committees confirmed their commitment to and role in the project was conducted. Additionally, a list of the names, positions, academic credentials, and professional experiences of academic and non-academic staff starting with the members of the project management team, and followed by the participants involved in the project implementation was involved in the project. The participants CV's were also joined in an Annex.

The project methodology included many activities, such as meetings, development of tools for data collection, data collection, needs analysis, SWOT analysis, reviewing the Faculty of Nursing Bylaw, reviewing relevant and recent literatures, developing standardized theoretical and clinical examinations, formation of books, brochures, and posters including the guidelines and the instructions of the new developed assessment methods, and preparation of the infrastructure of OSCE lab, the unit of electronic system for students' evaluation, the printing center of the faculty, and the question bank lab. Additionally, workshops on the developed students' assessment methods were conducted for both students and staff members. Data were collected through questionnaires, letters and interviews. Findings suggest the benefits of the project to both the students as well as the teaching staff. Both are able to identify and use the developed methods of students' assessment, such as Objective Structured Clinical Evaluation, the objective exams (multiple choice questions "M.C.Q.", true and false questions "T \& F", and the matching questions), the acquisition of skills to adopt the electronic system for students' evaluation, and to formulate a question bank for the six scientific nursing departments at 
the Faculty of Nursing Tanta University Egypt.

1) The project basic data:

Project Title: 'Development of Students'

Assessment to Conform Academic

Standards at Faculty of Nursing Tanta University"

Project Acronym: "Multiple stations

Examination/Clinical Skill
Assessment/Standardized Patient

Examination, Objective Assessment, \&

Academic Standards/ Faculty Bylaw"

Institution: "Tanta University Faculty of

Nursing"

Project Partners:Tanta University and

Program of Continuous Improvement and

Qualification for Accreditation

\section{Budget Information:}

A. Requested fund (from Program of Continuous Improvement and Qualification for

Accreditation)

B. Total co-financing from Tanta University

C. Total co-finance from other partners

Total Budget (Sum A + B + C):

The following were the financial constraints that had to stick for:

Tanta University Institutional Co-financing of the project was $40 \%$ and the "Program of Continuous Improvement and Qualification for Accreditation $60 \%$.
$(\mathrm{L} . \mathrm{E})=535000$

$($ L.E $)=400000$

$(\mathrm{L} . \mathrm{E})=000000$

(L.E) $=935000$

Project Size: Large

Project duration: (18) Months + (6)

Months extended due to the circumstances encountered by the country at the time of implementation of the project, started from October 2009 to September 2011.

\section{2) Project Team:}

Table (1) indicate the number of staff involved in the project

\begin{tabular}{|l|l|}
\hline Category & $\begin{array}{l}\text { Number of Staff involved in the } \\
\text { project }\end{array}$ \\
\hline I. Administrative Committee / Project Management Team \\
\hline Assistant Staff: & 2 \\
\hline Teacher/lecturer/Assistant Professor: & 6 \\
\hline Associate Professor: & 1 \\
\hline Professor: & 2 \\
\hline II. Implementation Committee / Project Implementation Team \\
\hline
\end{tabular}




\begin{tabular}{|l|l|}
\hline Assistant Staff: & 10 \\
\hline Teacher/lecturer/Assistant Professor: & 7 \\
\hline Associate Professor: & 1 \\
\hline Professor: & 1 \\
\hline Non-academic Staff: & 6 \\
\hline $\begin{array}{l}\text { Total number of academic and non-academic staff involved in } \\
\text { the Project: }\end{array}$ & 36 \\
\hline
\end{tabular}

\section{3) Faculty / Institute Data:}

University: Tanta University

Faculty/Institute: Faculty of Nursing

The date of establishment of the Faculty: 1982

Table (2) Total number of the Faculty/Institute students for academic year: 2008/2009

\begin{tabular}{|c|c|c|c|c|}
\hline $\begin{array}{c}\text { First } \\
\text { year }\end{array}$ & $\begin{array}{c}\text { Second } \\
\text { year }\end{array}$ & $\begin{array}{c}\text { Third } \\
\text { Year }\end{array}$ & $\begin{array}{c}\text { Fourth } \\
\text { year }\end{array}$ & Total \\
\hline 384 & 346 & 319 & 409 & 1458 \\
\hline
\end{tabular}

Table (3) Total number of the postgraduate students for academic year:

\begin{tabular}{|c|c|c|c|}
\hline Diploma & Master & PhD & Total \\
\hline 0 & 71 & 30 & 101 \\
\hline
\end{tabular}

Table (4) Number of the staff members of the faculty:

\begin{tabular}{|c|c|c|c|c|}
\hline Prof. & Assoc Prof. & Lecture & Total & $\begin{array}{c}\text { Number of the outside or } \\
\text { leave }\end{array}$ \\
\hline 3 & 2 & 43 & 48 & 25 \\
\hline
\end{tabular}

Table (5) Number of Assistance:

\begin{tabular}{|c|c|c|c|}
\hline $\begin{array}{c}\text { Assistant } \\
\text { Lecturer }\end{array}$ & Demonstrator & Total & $\begin{array}{c}\text { Number of the outside or } \\
\text { leave }\end{array}$ \\
\hline 32 & 24 & 56 & 4 \\
\hline
\end{tabular}

Table (6) The number of faculty administrators:

\begin{tabular}{|c|c|c|c|c|}
\hline $\begin{array}{c}\text { Student } \\
\text { affair }\end{array}$ & $\begin{array}{c}\text { Financial } \\
\text { management }\end{array}$ & $\begin{array}{c}\text { Other administrative } \\
\text { affairs }\end{array}$ & Postgraduate & Technicians \\
\hline 5 & 8 & 21 & 1 & 10 \\
\hline
\end{tabular}


Table (7) Educational programs granted by the faculty (undergraduate):

\begin{tabular}{|c|c|c|}
\hline SN & Program & Program courses \\
\hline 1 & Bachelor Degree in Nursing Science & 43 \\
\hline \multicolumn{2}{|c|}{ Total number of programs = 1 } & Total number of courses (unrepeated) $=43$ \\
\hline
\end{tabular}

\section{Duration of the program:}

Four years + one year internship

Program level (in the credit hour system):

Not Applicable

Table (8) Educational programs granted by the faculty (postgraduate): ten programs

\begin{tabular}{|c|l|c|}
\hline SN & \multicolumn{1}{|c|}{ Program } & Program courses \\
\hline 1 & Medical Surgical Nursing Departments & 8 \\
\hline 2 & Maternity and Gynecological Nursing & 8 \\
\hline 3 & Pediatric Nursing & 70 \\
\hline 4 & Psychiatric Nursing & 7 \\
\hline 5 & Public Health Nursing & 7 \\
\hline 6 & Nursing Service Administration & 8 \\
\hline 7 & Critical Care Nursing & 6 \\
\hline 8 & Geriatric Nursing & 8 \\
\hline 9 & Nursing Education & 6 \\
\hline 10 & AIDS Nursing & Total number \\
\hline \multicolumn{2}{|c|}{ Total number of programs $=6$} & of courses (unrepeated) $=74$ \\
& &
\end{tabular}

\section{List of scientific Departments:}

1- Medical Surgical Nursing Departments

2- Maternity and Gynecological Nursing Departments

3- Pediatric Nursing Departments

4- Psychiatric Nursing Departments

5- Public Health Nursing Departments

6-Nursing Service Administration Departments 
Table (9) Ratio of the staff member to the students

\begin{tabular}{|l|c|}
\hline Ratio of the staff member to the students & $1: 32$ \\
\hline Ratio of the staff member on-the-job to the students & $1: 64$ \\
\hline
\end{tabular}

\section{Background:}

Faculty of Nursing, Tanta University is competing to achieve accreditation through implementation of the Quality Assurance System in nursing education. As development of students' evaluation system is one of the Quality Assurance System requirements, the faculty is trying to adopt new objective methods of evaluation. So long as assessment of theoretical and clinical competence is of great importance when evaluating the expected learning outcomes of nursing education, our faculty challenges in assessing both the theoretical and clinical competences. Although nursing educators applied various methods in an attempt to find an appropriate tool, including written and oral exams, seminars, role play, group discussion short and long practical cases, yet the majority of examinations at the faculty are of the old traditional type. They are neither evidence-based nor communitybased nor performance-based assessment methods. They are unreliable, invalid and non objective. The conventional clinical and theoretical examination is beset with several problems. Most of the methods used have proved to be deficient or defective in meeting the five most important criteria of objective examination that ensure that standards of evaluation, standards of care for patients and standards of practice for nurses are met. These criteria include: systematic, measurable, attainable applicable, valid and reliable, and tangible / time bounded examination. Although marking should depend only on student variability, patient and procedures variability and examiner variability significantly affect students' scoring. The subjectivity involved may reduce the marks awarded by different examiners for the same students' performance. The marks awarded also reflect only the global performance of the students and are not based on demonstration of individual competencies and creativity. Problems in communication significantly affect the outcome. Attitudes are usually not tested at all by the conventional examination, and the student is questioned 
only regarding the final conclusion. The final score indicating student' overall performance gives no significant feedback to the student. The ability to examine a student and arrival at a conclusion is not observed by the examiners/staff members. Additionally, the examination code of practice (faculty evaluation bylaw) is not developed/revised/ renewed to meet the current academic nursing standards in nursing education and the program intended learning objectives/outcomes. Also, there is no electronic system for student evaluation, and there is no question bank. As a result of limitations involved in the evaluation system at the Faculty of Nursing Tanta University, graduates are up to the level required. Investigating the stakeholders' needs and evaluation of the current graduates is unsatisfactory. Nurses are not competent and do not satisfy and community needs.

\section{Scope:}

Student Evaluation Project covered the entire undergraduate as well as two of the postgraduate nursing courses over a period of 18 months. The code of practice was structured, revised and approved by the faculty council. Infrastructure and modifications suitable for the new system was established. Staff members were trained to effectively apply the new methods of evaluation. Also students were trained on those new methods before being implemented. The project plan and outcomes were monitored and evaluated. The project beneficiaries included: student nurses, staff members, patients, families, hospitals, health care system, and the community as a whole got benefit from graduation of competent nurses that satisfy stakeholders' needs. The project importance included enhancement of the Faculty of Nursing and Tanta University national strategy of education development. The project implementation helped the faculty to overcome the problems encountered in the previous examinations system; guarantee continuous improvement as a step to meet the requirements of the National Accreditation Committee in Egypt; enhanced teaching and learning process; met the academic standards; met the faculty mission and vision; graduate competent professional nurses at national, regional, and international standards who will be able to provide evidence based nursing, culturally sensitive communication, ethical principles, awareness and responsiveness to health care 
system, satisfy stakeholder's needs, and compete for excellent positions.

\section{Objectives:}

The project objectives were (1) development of examination code of practice (faculty evaluation bylaw revision, renewal and approval of the examination items), (2) development of objective theoretical and clinical examinations, (3) adoption of electronic system for student evaluation, and (4) adoption of a question bank. The project assumptions included: (1) Development of objective summative and formative tools for assessment of theoretical and clinical examinations that meet the academic standards, (2) Solving problems encountered by the present evaluation system. (3) Attainment of one of the requirements of the National Accreditation Committee in Egypt.

\section{Description:}

The project included: (1) Development of examination code of practice (faculty evaluation bylaw revision and renewal). The code of practice described the conduct of objective formative and summative assessment of the nursing courses of the undergraduate curriculum and of two courses of the postgraduate programs at the Faculty of Nursing Tanta University. Details of the responsibilities of various boards and committees which relate to this Code of Practice were available at faculty student handbook and in a brochure for evaluation rules, and at Tanta University website. (2) Development of objective theoretical and clinical examinations. (3) Adoption of electronic system for student evaluation, and (4) Adoption of a question bank. The project supported a large number of the Faculty of Nursing Tanta University students of undergraduate nursing program of six nursing departments /specialties (Fundamental and Medical Surgical Nursing, Maternity and Gynecological Nursing, Pediatric Nursing, Community Health Nursing, Psychiatric Nursing, and Nursing Service Administration). Additionally, the new developed student assessment system was implemented on two courses of the post graduate nursing programs. The project period was 18 months extended 6 more months.

\section{Methodology and the faculty experience with the project: \\ Faculty of Nursing Tanta University faces several problems in students' evaluation system. These include: the examination code of practice (faculty evaluation bylaw) is not}


developed to meet academic standards, absence of objective theoretical and clinical examinations, there is no electronic system for student evaluation, and there is no question bank. The project included the following steps: (1) formation of assessment committees [three months]; (2) preparation of the infrastructure [six months]; (3) searching, and sourcing [three months]; (4) development of the evaluation code of practice (review and renew of the faculty evaluation bylaw, development of drafts, assessment of opinions, development of final version, approval from the faculty council, and dissemination among different stakeholders [six months]; (5) development of objective theoretical and clinical examination (conduction of thirty six workshops for training of staff for the six scientific nursing departments in the Faculty, development of drafts, assessment of opinions, development of final versions for the six nursing departments) [three months]; (6) development of an electronic system for student evaluation [six months]; (7) conduction of six meetings for training and examining students using the new developed examination methods [three months]; and (8) formation of a question bank [three months]. The project period was 18 months extended 6 more months and some of the activities were overlapped in the timescale.

\section{Needs Analysis:}

Faculty of Nursing Tanta University is trying to achieve accreditation through implementation of the Quality Assurance System in nursing education. Development of students' evaluation system at Faculty of Nursing Tanta University is one of the Quality Assurance System requirements. In this regard, assessment of theoretical and clinical competences is of great importance. Assessment of students at Faculty of Nursing Tanta University did not measure high levels of competencies, and creativity in examinations. Graduates are not professionally competent based on assessment of stakeholders' opinions. Stakeholders' opinions indicated that the present evaluation system is not evidence base and the exams did not measure the actual performance of the students. Such limitations led to the disability of the nursing graduates to meet the needs of the patients and the market, and led to community dissatisfaction with the faculty graduates. Faculty of Nursing Tanta 
University is in need to use the most valid and reliable methods of students' evaluation in order to overcome the limitations encountered in its theoretical and clinical examinations to become an integral component of the entire teaching and learning process, and to meet the community needs.

\section{SWOT Analysis:}

The strengths included in the present evaluation system were supportive administration of the faculty, variability in staff experiences, and implementation of some objective examinations, e.g. Multiple Choice Questions (M.C.Q.)

The weaknesses included in the present evaluation system were subjectivity; problems in communication; attitudes are usually not tested; no significant feedback to the student; examination do not meet the program Intended Learning Objectives/Outcomes (ILOs); examinations do not measure competencies and creativity; and the examinations do not measure the three domains of nursing education (knowledge, skills, and attitudes). On the other hand, there are some opportunities that will enhance the present evaluation system.
The opportunities included in the present evaluation system were project fund and an opportunity to change and correct the present evaluation system.

The threats included in this project were the resistance of the staff to implement the new developed evaluation system, refusal of the staff to implement the new methods adopted by the faculty, staff withdrawal from the project for different reasons e.g. traveling abroad, and discontinuation of the project fund, time and money limitations, retardation in admission of a time/stage report of the project, administrative barriers, and change of the university presidents. In order to overcome the threats/risks, the following strategies were applied: The stakeholders were involved in the project activities; their opinions were assessed; further explanation were given for those who ask for; handouts, poster, and a portfolio were provided; thirty six workshops and six meetings were conducted; involvement of the faculty administration by attending and providing regular reports about the project progress; and getting approval of the new developed students' assessment by the faculty council. 


\section{Activity plan and implementation}

The project specific objectives are: (1) develop/review/renew and approve the faculty examination code of practice (faculty evaluation bylaw), (2) develop objective theoretical and clinical examinations,

(3) adopt an electronic system for student evaluation, and (4) establish a question bank. The project objectives attained through the following activities:

(1) Available committees for conduction of various project objectives and activities, e.g. a committee for reviewing and renewing the faculty evaluation bylaw, and a committee for constructing and reviewing examinations. This output faced staff resistance and lack of cooperation [three months]. (2) Preparation of the infrastructure [six months]. This output faced by lack of resources in the term of place, money and people. (3) Available Code of Practice for students' evaluation (sourcing and searching, review and renew of the faculty evaluation bylaw, making drafts, assessment of opinions, development of final version, approval from the faculty council, and dissemination among different stakeholders [six months]. (4) Available of the Objective
Structured theoretical and clinical examinations [six months] for the six nursing departments and 2 post graduate courses (conduction of thirty six workshops for training of staff, development of drafts, assessment of opinions, development of final versions, training and examining students using) the developed assessments [six months]. This output faced inability of staff members to use information technology, lack of staff and students' cooperation, and lack of human and non human resources. (5) Available electronic system for students' evaluation [three months]. This output faced lack of resources in the term of place, money and people, and staff and administrative resistance. Available question bank [three months] included formative and summative examinations. This output faced by lack of resources and staff cooperation. The project resources included human and non human resources, such as personnel, money, physical environment, computers, printers, photocopy machines, scanner, papers, manikins, video cameras, electronic machine for students' assessment, and six OSCE stations, etc. 


\section{Logical Framework Matrix}

\begin{tabular}{|c|c|c|c|}
\hline Code & $\begin{array}{c}\text { Specific } \\
\text { Objective(s) }\end{array}$ & $\begin{array}{l}\text { Outputs/ } \\
\text { Outcomes }\end{array}$ & Activities \\
\hline \multirow[b]{2}{*}{ I } & \multirow{2}{*}{$\begin{array}{l}\text { (1) } \\
\text { Development } \\
\text { of Code of } \\
\text { Practice for } \\
\text { students' } \\
\text { evaluation. }\end{array}$} & $\begin{array}{l}\text { 1.1. Available } \\
\text { evaluation committees } \\
\text { for revision, and } \\
\text { renewal of faculty } \\
\text { evaluation bylaw, and } \\
\text { development of } \\
\text { student assessments. }\end{array}$ & $\begin{array}{l}\text { 1.1.1. Invitation of staff for participation in the } \\
\text { committees } \\
\text { 1.1.2. Conduction of } 3 \text { meetings for appointment of staff } \\
\text { for various evaluation committees (1 committee for } \\
\text { development of code of practice, electronic system, and } \\
\text { the question bank, and } 6 \text { committees for development of } \\
\text { theoretical and clinical objective assessments for the } 6 \\
\text { nursing departments). A subcommittee from the } 6 \\
\text { committees will be assigned for preparation of the } \\
\text { infrastructure needed for the various project objectives, } \\
\text { e.g. OSCE stations }\end{array}$ \\
\hline & & $\begin{array}{l}\text { 1.2. Available new } \\
\text { evaluation bylaw/code } \\
\text { of practice with } \\
\text { details of the } \\
\text { responsibilities of } \\
\text { various boards and } \\
\text { committees which } \\
\text { relate to this Code of } \\
\text { Practice, } \\
\text { documentation of } \\
\text { marks and grads, and } \\
\text { other concepts }\end{array}$ & $\begin{array}{l}\text { 1.2.1. Assessment of opinions regarding the present and } \\
\text { the new developed evaluation bylaw through } \\
\text { questionnaires } \\
\text { 1.2.2. SWOT analysis } \\
\text { 1.2.3. Searching and sourcing, development of drafts, } \\
\text { development of the final version of the new code of } \\
\text { practice, and approval by the faculty council } \\
\text { 1.2.4. Dissemination through faculty student handbook } \\
\text { and a brochure }\end{array}$ \\
\hline \multirow{3}{*}{11} & \multirow{3}{*}{$\begin{array}{l}\text { (2) Adoption } \\
\text { of } \\
\text { standardized } \\
\text { competency- } \\
\text { based } \\
\text { assessments. }\end{array}$} & $\begin{array}{l}\text { 2.1. Available } \\
\text { infrastructure suitable } \\
\text { for the developed } \\
\text { students' clinical and } \\
\text { theoretical } \\
\text { assessments }\end{array}$ & $\begin{array}{l}\text { 2.1.1. Preparation of } 6 \text { OSCE stations for assessment of } \\
\text { clinical competencies for the } 6 \text { nursing departments } \\
\text { 2.1.2. preparation of a photocopy center equipped with } \\
\text { necessary machines for safe exams printout } \\
\text { 2.1.3. preparation of a suitable place fulfilling the } \\
\text { requirements for the question bank }\end{array}$ \\
\hline & & $\begin{array}{l}\text { 2.2. Trained staff on } \\
\text { the development of } \\
\text { objective assessments }\end{array}$ & $\begin{array}{l}\text { 2.2.1. conduction of } 6 \text { workshops for training the staff } \\
\text { of the } 6 \text { nursing departments on the development of } \\
\text { objective assessments, criteria of examination paper, the } \\
\text { electronic system for students' evaluation, and } \\
\text { categories and subcategories of examinations for the } \\
\text { question bank } \\
\text { (pre test and post test will be done, and needs } \\
\text { assessment) }\end{array}$ \\
\hline & & $\begin{array}{l}\text { 2.3. Available } \\
\text { objective summative } \\
\text { and formative tools } \\
\text { for students' } \\
\text { assessment for }\end{array}$ & $\begin{array}{l}\text { 2.3.1. development of drafts for the } 6 \text { nursing } \\
\text { departments } \\
\text { 2.3.2. assessment of opinions regarding the developed } \\
\text { tools } \\
\text { 2.3.3. peer reviewing }\end{array}$ \\
\hline
\end{tabular}




\section{Tanta Scientific Nursing Journal}

\begin{tabular}{|l|l|l|}
\hline $\begin{array}{ll}\text { theoretical and clinical } \\
\text { competencies and } \\
\text { measure the ILOs of } \\
\text { the faculty program } \\
\text { and the courses. }\end{array}$ & $\begin{array}{l}\text { 2.3.4. development of final versions based on the } \\
\text { obtained comments } \\
\text { 2.3.5. Expert reviewing }\end{array}$ \\
$\begin{array}{l}\text { 2.4. Trained students } \\
\text { on the use of the new } \\
\text { assessment methods. }\end{array}$ & $\begin{array}{l}\text { 2.41. orientation/training of students on the use of the } \\
\text { new developed assessments (OSCE and other methods) } \\
\text { 2.4.2. routine assessment using the developed objective } \\
\text { assessments } \\
\text { 2.4.3. assessment of feedback }\end{array}$ \\
\hline
\end{tabular}

\section{Logical Framework Matrix}

\begin{tabular}{|c|c|c|c|}
\hline Code & $\begin{array}{c}\text { Specific } \\
\text { Objective(s) }\end{array}$ & $\begin{array}{l}\text { Outputs/ } \\
\text { Outcomes }\end{array}$ & Activities \\
\hline \multirow[b]{2}{*}{ III } & \multirow{2}{*}{$\begin{array}{l}\text { (3) Adopt an } \\
\text { electronic } \\
\text { system for } \\
\text { students' } \\
\text { evaluation. }\end{array}$} & $\begin{array}{l}\text { 3.1. Available equipment needed } \\
\text { for electronic system for students' } \\
\text { evaluation }\end{array}$ & $\begin{array}{l}\text { 3.1.1. purchase of the electronic machine for } \\
\text { students' assessment }\end{array}$ \\
\hline & & $\begin{array}{l}\text { 3.2. Available instructions on the } \\
\text { assessment of students using the } \\
\text { electronic system }\end{array}$ & $\begin{array}{l}\text { 3.2.1. Formulation of a portfolio that include } \\
\text { staff members, students, and administrators } \\
\text { directions on the use of the electronic system } \\
\text { for students' evaluation }\end{array}$ \\
\hline IV & $\begin{array}{l}\text { (4) } \\
\text { Formation of } \\
\text { a Question } \\
\text { Bank. }\end{array}$ & $\begin{array}{l}\text { 4.1. Available question bank that } \\
\text { include } 6 \text { categories and } \\
\text { subcategories for assessing } \\
\text { theoretical and clinical } \\
\text { competencies that include } \\
\text { knowledge, understanding, skills, } \\
\text { attitudes, and communication. }\end{array}$ & $\begin{array}{l}\text { 4.1.1. Preparation of the infrastructure and } \\
\text { development of drafts of templates and } \\
\text { categories for each course/or department } \\
\text { 4.1.2. Development of final versions of the } \\
\text { templates for each department/ category and } \\
\text { subcategories }\end{array}$ \\
\hline
\end{tabular}




\section{Feedback}

Feedback of the students upon whom the evaluations implemented were assessed to evaluate the pros and cons met with during implementation. Community and stakeholders feedback was assessed in order to ensure the benefit of the implementation of the project.

\section{Project Outputs/Outcomes:}

The project outcomes included availability of objective summative and formative tools for assessing theoretical and clinical competencies that include knowledge and understanding, skills and attitudes, meet community and labor market needs; and are transparent and fair, availability of electronic examinations; available unit for electronic assessment, ; existence of a Question Bank, trained staff on the development of the new student assessments; and students' assessment using the new developed tools and methods, prevention of private classes, evaluation committees will be available for development, revision, and renewal of evaluation rules and examinations to meet national, regional, and international standards, and dissemination of evaluation rules among students, staff, and administrators. Additional project outcomes included: (1) students and graduates provide patients with competent nursing care at the six nursing specialties of Faculty of Nursing Tanta University. (2) Students communicate effectively in a culturally sensitive manner with the patients. (3) Students acquire knowledge and skills needed for effective patient care. (4) Students use information technology for the benefit of their patients. (5) Students provide evidence based nursing. (6) Students demonstrate professionalism, ethical principles, and an awareness of and responsiveness to the larger context of health care system. Graduation of competent nurses at national, regional, and international standards. The outcomes also involved available objective fair evaluation examinations; available evaluation committee for development, revision, renewal of faculty evaluation bylaw,

available developed code of practice for students' assessment (new evaluation bylaw), available evaluation rules and ethics in documents.

\section{Dissemination and Sustainability:}

The project dissemination through:

Conduction and or participation in national and international conferences and workshops, seminar/round table discussion and meetings, and publication in faculty student handbook, brochure, posters, books, and university web-site. The project 
sustainability is influenced by three major groups of factors, and five important sub factors: (1) project design and implementation factors: (a) the project outcomes modification over time, (b) the "champion"/responsible committee present, (2) factors within the organizational setting: (c) the project "fits" with the faculty mission and procedures, (d) perceived benefits to staff members and/or clients, and (3) factors in the broader community: (e) stakeholders in other organizations provide support. Important categories of indicators of the project sustainability include: (1) maintenance of benefits achieved through project, (2) level of institutionalization of the project within the faculty and (3) measures

of capacity building in the recipient, i.e. staff members and their assistants, and the students.

\section{The long-term perspective for project} results/outcomes includes financial sustainability, and. sustainability at the policy level.

Financial sustainability of the project activities through: (1) allocation of an examination fee will be obtained, (2) renting the project equipment for similar agencies (nursing and health sciences), and (3) conduction of paid workshops.
Institutional sustainability through (1) maintenance of the project equipment (OSCE stations, manikins, electronic system machine, computers, printers, photocopy machine, lab top, and data show projector) and continue to use for long-time; (2) regular revision and renewal of the evaluation code of practice; (3) regular revision and renewal of the developed students' assessment methods and procedures of both clinical and theoretical components of the program of study; (4) maintenance of the project infrastructure, i.e. Question Bank and the printing center in place equipped with the necessary equipments; and (5) keeping the project materials and documents in a well conducted recording and reporting system. Sustainability at the policy level: include quality control and monitoring, peer and experts reviewing, recording and reporting system of activities, and inter- Program of Continuous Improvement and Qualification for Accreditation project coaching (auditing, monitoring, and reviewing). The overall project management implemented based on management structure and decision making process. Management of the project used a scientific management approach for management of committees, resources, activities, and evaluation 
timeline, for planning, organizing, leading and controlling the project teems, and activities. Critical thinking technique was used for decision making to guide the project decisions, actions and beliefs through a rigorously and skillfully use of information, experience, observation and reasoning. For effective structure management of this project, role and responsibility of each member of the project management team was identified. Job classification, job descriptions, understanding of interpersonal skills, providing motivation, e.g. Financial rewards based on doing good job, special compensation for overtime and extensive travel, and performance appraisal. Conflict resolution by establishing priorities, good planning, and consideration of specialties of individuals, and use of continuous formal and informal communication between team members

\section{Project summary:}

Development of students' Assessment to conform academic standards at Faculty of Nursing Tanta University constitutes a critical need for a systematic, measurable, attainable/ applicable, valid/reliable, and tangible / time bounded assessment. It is important to avoid exam subjectivity, improve communication, graduate competent nurses, and satisfy the community needs. The project objectives were to: review and renew of the faculty evaluation bylaw; disseminate examinations rules, adopt standardized theoretical and clinical competency-based summative and formative tools, adopt an electronic system for students' evaluation; and establish a Question Bank. The project implementation helps to overcome the problems encountered by the previous examinations system, and helps to meet one of the requirements of the National Accreditation Committee in Egypt, and meet the academic standards. The project included: formation of various committees, construction of various objective assessments, preparation of the infrastructure (OSCE stations, the unit of electronic system for students' evaluation, and the question bank), training of staff members, their assistants and students, and examination entry for the question bank. The new objective assessments met the psychometric and logistic assessment criteria in assessing many fundamental components of theoretical information and clinical skills, as well as the transferable skills not covered in other evaluations. The impact of realization of the present project benefit students, staff members and their assistants, patients, health care sectors, and the community. Graduates of the Faculty 
of Nursing will provide practical solutions, innovate, create, deal with the technological advances, and conduct outstanding scientific research to protect the community against health hazards at national, regional and international level. Graduates provide competent nursing care, effective culturally sensitive communication; use information technology and evidence based nursing, and demonstrate professionalism, ethical principles, awareness of and responsiveness to the health care system.

\section{References:}

1) El-Adham, A. et al. "Development of Students' Assessment System to Conform Academic Standards at Faculty of Nursing Tanta University". Project of Continuous Improvement and Qualification for Accreditation" of higher education in Egypt. The Egyptian Ministry of higher education and Tanta University Egypt 2009.

2) Mundt MH, Clark Procaccini M, and Klemczak Wrona J. A Task Force Model for Statewide Change in Nursing Education Building Quality and Safety. Journal of Professional Nursing.Retrieved from http://www.rwjf.org/en/researchpublications/find-rwjf-research.2013
3) Iain.R. Exploring approaches to clinical skills development in nursing education. Nursing Times; 2009;105 (3): 20-22.

4) The Egyptian Ministry of higher education. Code of the Bet Practices for Students' Assessment in Higher Education.1st draft.Revision 5.

5) Frances M. Hill."Managing service quality in higher education: the role of the student as primary consumer". Quality Assurance in Education, 1995; 3(3): $10-21$.

6) Conole,G. The Role of Evaluation in the Quality Assurance of eLearning. Summer.Learning and Teaching in Action. 2004;3(1): 9

7) Susan M. Brookhart, Helena, MT. Developing Measurement Theory for Classroom Assessment Susan M. Brookhart, Helena, MT. Developing Measurement Theory for Classroom Assessment. Purposes and Uses. Winter Educational Measurement: Issues and Practice 2003.

8) NLN Board of Governors. Transforming Nursing Education: Leading the Call to Reform. Academic Progression in Nursing Education A Leving Document from the National League for Nursing 2011. 
9) Benner, P., Sutphen, M., Leonard, V., Day, L. Educating Nurses: A Call for RadicalTransformation.San.

Francisco, CA; Jossey-Bass2010.

10) Institute of Medicine. The Future of Nursing, Leading Change, Advancing Health. Washington, DC:Author 2011.

11) Matthew W. Short, John A. Edwards, Madigan Army. Assessing Core Competencies with an Objective Structured Clinical Examination. The ACGME Outcome Project: An Introduction.. Accreditation Council for Graduate Medical Education. Review 2005

12) National League for Nursing. Academic/Professional Progression in Nursing [Reflection and Dialogue. Retrievedfrom

www.nln.org/aboutnln/reflection_dial ogue/refl_dial_2.htm2007.

13) National League for Nursing. Outcomes and Competencies for Graduates of Practical/ Vocational, Diploma, Associate Degree, Baccalaureate, Master's, Practice Doctorate, and Research Doctorate Programs in Nursing. New York2010.

14) Tri-Council for Nursing. Educational Advancement of Registered Nurses: A Consensus Position. Retrieved from www.nln.org/newsreleases/tri-council. 2010.

15) Bruffee, Kenneth A. Collaborative learning: Higher education, interdependence, and the authority of knowledge.. Johns Hopkins University Press. Baltimore. 2002; 227-233.

16) Robert Wood Johnson Foundation. Transforming Nursing Education to Meet Emerging Health Care Needs. 2013. Route 1 and College Road East, P.O. Box 2316 Princeton, NJ 08543.

17)Mundt $\mathrm{MH}$, Clark Procaccini $\mathrm{M}$, and Klemczak Wrona J. A Task Force Model for Statewide Change in Nursing Education Building Quality and Safety.. Journal of Professional Nursing.Retrieved http://www.rwjf.org/en/researchpublications/find-rwjf2013-

18)Center for Teaching and Learning Division of Academic Affairs. One Hundred Methoss. The University of North Carolina at Charlotte 2013.

19)Jackson. S. 3 New Teaching Methods: Improve the Educational Process. 2012. Learning. Learning Innovation.

20)South African Qualification Authority. Criteria and Guidelines for Assessment of NQF Registered Unit Standards and Qualifications. Policy document. Directorate: Quality Assurance and Development. Waterkloof, Pretoria2001. 


\section{Tanta Scientific Nursing Journal}

21)Kou M. Objective Test Formats. How to Construct Objective Test Itens. Effect of Objective Test Items on Teaching and Learning.The Gale Group, Inc. Retrieved from:http://www.education.com/reference/ article/objective-test-items/2010
22)Faculty of Nursing Tanta University. The Education Bylaw. 2003. 
